\title{
A magán- és a közszféra határán: a hatósá- gi tevékenységek integritási kockázatainak és kontrolljainak vizsgálata
}

\author{
Martus Bettina Szandra - Németh Erzsébet - \\ Vargha Bálint Tamás \\ https://doi.org/10.51624/SzocSzemle.2019.3.1 \\ Beérkezés: 2018. 05. 23. \\ Első átdolgozott változat beérkezése: 2018. 11. 20. \\ Utolsó átdolgozott változat beérkezése: 2019. 07. 15. \\ Elfogadás: 2019. 09. 03.
}

\begin{abstract}
Összefoglaló: Az Állami Számvevőszék 2017-ben hetedik alkalommal mérte fel a közintézmények integritási helyzetét, integritás kockázatait és a kockázatokat mérséklő kontrollok szintjét. Tanulmányunkban a közhatalmi feladatokat ellátó intézmények integritási helyzetét elemezzük a 2017. évi felmérés adatai alapján. A hatósági jogkörrel rendelkező szervezeteknél a kutatás integritáskockázatként azonosította az egyedi mérlegelésen alapuló döntési jogkört, a méltányosság gyakorlását, az engedélyezési, ellenőrzési, szabálysértési hatósági, illetve szakhatósági véleményezési jogkört. Miközben az integritáskontrollok kiépítettsége általában megfelelő szintű, a külső és belső bejelentők védelme, a munkahelyi rotáció alkalmazása és a kapcsolattartási szabályok nincsenek megfelelően kiépítve. Eredményeink azt mutatják, hogy az eltérő kockázati szinttel (alacsony, közepes, magas) rendelkező intézmények kontrollszintjei nem mutatnak különbségeket. Akár magasabb, akár alacsonyabb a kockázati szint, a kontrollok kiépítettsége közel azonos. A hatósági jogköröket gyakorlók esetében a kontrollok ezen „rugalmatlansága” hol kontrollhiányt, hol pedig túlkontrolláltságot okoz. Ezzel ellentétben a közszféra egészét vizsgálva a magasabb kockázatokat általában követi a kontrollok erősebb kiépítettsége is.
\end{abstract}

Kulcsszavak: integritás, közhatalmi tevékenység, kockázat, kontroll

\section{Közhatalmi tevékenység és korrupció}

A korrupció olyan tranzakciós gyakorlat, társadalmi értékzavar, amely közvetlenül hátrányos gazdasági következményekkel jár (Ivanyna et al. 2016) és rombolja a gazdasági célok eléréséhez is nélkülözhetetlen bizalmat (Tóth 2009). A korrupció alaposabb megértése hazánkban is indokolt, Keller és Sik (2009) tanulmányukban arra jutottak, hogy Magyarországon a lakosság „toleranciaszintjéhez” képest magasabb az észlelt korrupció.

Ismert összefüggés, hogy a korrupció kockázata a köz- és a magánszféra érintkezési pontjain jelenik meg (lásd Søreide 2014; Economakis et al. 2010). A korrupció nem egyéb, mint ha valaki a rábízott hatalommal személyes előnyök szerzése érdekében visszaél. Az állam eminens módon az az intézmény, amelynek tisztviselői és 
alkalmazottai nem saját hatalmukat gyakorolják, hanem az állam nevében járnak el. Így nyújtanak szolgáltatásokat, hoznak meg gazdasági döntéseket, gyakorolják a köz hatalmának rájuk eső részét, ugyanakkor a közjó céljának szolgálatától személyes előnyök szerzésének lehetősége el is térítheti őket.

A modern állam múködése során a közület és a magánszereplők találkozása alapvetően három területen megy végbe: az állam és a magánszereplők közötti üzleti tranzakciók, az állam által nyújtott közszolgáltatások igénybevétele, valamint a közhatalmi tevékenység gyakorlása körében. Az ÁSZ 2011 óta lefolytatott integritásfelmérésének eredményeit feldolgozó elemzések különböző nézőpontokból már korábban is vizsgálták ezen területek integritási helyzetét (Németh et al 2017; Németh-Vargha 2017; Vasvári et al. 2017). Panelkutatás vizsgálta, hogy a 2013 és 2016 közötti időszakban milyen változások történtek a közszféra korrupciós veszélyeztetettsége és korrupcióellenes kontrolljainak kiépítettsége körében. A kutatás megállapította, hogy a szignifikáns változások összefüggésben vannak a szervezetek jogállásának és feladatkörének módosulásával. A központosítások hatására az integritási kockázattal járó tevékenységet magasabb szintű kontrollokkal rendelkező közintézmények látták el (NémethVargha 2017). Az állam által biztosított közszolgáltatásokat (oktatás, egészségügy, szociális ellátás) nyújtó intézmények körében végzett kutatások szerint a korrupciós veszélyt jelző kockázatok és az azokat mérsékelni képes kontrollok kiépítettsége együtt mozog, azaz minél magasabb a kockázati szint, annál magasabb a kontrollkiépítettség, miközben bizonyos jelentős korrupciós kockázatot hordozó tényezők mint például a közszolgáltatások iránti túlkereslet - kontrollokkal való lefedettsége elégtelen (Németh-Martus-Vargha 2018).

Ez utóbbi kutatás arra is rávilágított, hogy a hatósági, ellenőrzési funkcióval rendelkező intézménycsoportok (rendőrség, honvédelem), illetve a független állami szervek a közszolgáltató intézményektől eltérően viselkednek. Ezen intézmények integritáskontroll-szintje a kockázati szintjüktől függetlenül magas. Ez ráirányította a figyelmet az állami közhatalmi funkció integritási helyzetének önálló vizsgálatára.

$\mathrm{Az}$ állam szerveinek hatósági tevékenysége magában foglalja okmányok kiállítását, engedélyek kibocsátását, hatósági ellenőrzéseket, kötelezéseket, büntetés kiszabását. A modern állam ezen alapvető funkciója éppen úgy jellemezi a központi államhatalom szerveit, mint a helyi önkormányzatok tevékenységét. A hatósági jogkörök gyakorlása egyaránt kihathat a magánszemélyek és a gazdasági társaságok mindennapjaira, mivel a jogkör gyakorlása, vagy éppen annak elmaradása következménnyel jár az állampolgárok életében. A hatósági, más néven közhatalmi tevékenység a közigazgatás kifelé ható működését, külső igazgatását foglalja magában. A közigazgatási szerv hatalmi helyzete alapján a közhatalmi tevékenység szuprematív - hatalmi - pozícióra alapuló jogviszony. A közhatalmi, illetve hatósági jogviszony a hatósági jogkörrel felruházott közigazgatási szerveknek (hatóságoknak) a tőlük független személyekkel, illetve szervezetekkel szemben fennálló, közhatalmi jellegú jogviszonya, melynek célja az általánosan kötelező jogszabályok érvényesítése 
egyedi jogalkalmazó aktusokkal és egyedi jogérvényesítő cselekményekkel. A hatósági jogviszony általában kétpólusú viszony, amely a közigazgatási szerv (hatóság) és az ügyfelek között áll fenn. A hatósági jogviszony tárgya az ügyfél egy életviszonyában tanúsított magatartása (Fazekas-Ficzere 2006).

$\mathrm{Az}$ alattvalók/állampolgárok várakozásai a közhatalmi szervek tevékenységével szemben már igen korán - a modern állam ezen képességei kifejlődésének kezdetétől - korrupciós érdekeltséggel szembesítik a közhivatalokat (lásd Rubinstein-Maravic 2010). Az állam közhatalmi szerveinek aktusai a korrupciós piac klasszikus és keresett „portékája”. A korrupciós tranzakció tárgya a közhatalmi tevékenység körében tipikusan a hatóság döntése: feljogosító vagy kötelezést kimondó jogalkalmazó aktusa.

Mivel a korrupciós tranzakcióban az áru a döntés, a korrupciós veszély mértéke követi a hatóság, közhivatalnok döntési szabadságának mértékét. A hatósági döntés annál könnyebben válhat a korrupció tárgyává, minél szélesebb diszkrecionális lehetőség áll legálisan rendelkezésre (méltányosság, mérlegelési jogkör). A döntési spektrum szorosan összefügg azzal is, hogy egy személy vagy egy testület jogosult a tárgybéli döntést meghozni (lásd Søreide 2014, Søreide - Rose-Ackerman (2018). Jávor (2008) tanulmánya rámutat, hogy a közhatalmi szervek a szabályok alkalmazása helyett a hatósági és engedélyezési tevékenységet beviszik az üzleti piacra az egyedi esetekre. Szántó és társai (2011) a hatósági engedélyezéssel kapcsolatos korrupciónak szintén jelentős figyelmet szentelnek, esettanulmányuk az engedélyek megszerzéséhez kapcsolódó közvetítéses korrupció személyes és intézményes beágyazottságát vizsgálja.

\section{A hivatali korrupció elleni fellépés}

A közhatalmi döntések korrupciós érintettsége nem csupán az abban érintett hivatalnoknak juttatott jogtalan (anyagi) előny miatt jár társadalmi károkkal (igazságtalan elosztás, korrupciós járadék, társadalmi szintű bizalomvesztés), emellett az állami hatalom a hivatali korrupciós cselekményt a saját nézőpontjából döntési kompetenciáinak elvonásaként is értelmezi, és mint ilyet, a kezdetektől szankcionálja. A korrupt hivatalnok példás megbüntetését nem csupán a morális rend helyreállításának igénye, hanem a politikai racionalitás is megkövetelte: a hivatalnok visszaélése a rábízott hatalommal egyben engedetlenség, az uralkodó személyével, a szuverénnel szembeni hútlenség. A korrupciós cselekmény korábban általánosnak mondható büntetőjogi értelmezése szerint nem is lehetett más, mint kizárólag a közhivatalnok hivatali hatáskörében elkövetett visszaélése (lásd Kőhalmi 2013; Tóth 2015). Nem véletlen tehát, hogy - már az antikvitástól - éppen az ilyen magatartások (politikailag is motivált) szankcionálása a korrupcióellenes jogi fellépés kezdete is egyben (lásd Cepas-Dobryninas 2016). Ugyanakkor a korrupciós visszaélés kizárólag megtorláson alapuló büntetőjogi kezelése igen hamar el is érte saját határait. Ennek felismerésével a represszív eszközöket mindenütt egyre gyakrabban egészítik ki a korrupció megelőzését szolgáló szabályok (Klotz 2017). 
Az államhatalom centralizálása a korrupció elleni fellépéssel kéz a kézben járó, habár nem feltétlenül azonnal eredményre vezető törekevés (lásd Freille-Haque-Kneller 2007). Kézenfekvő megoldási kísérlet a korrupciós veszély eliminálására a köztisztviselő döntési kompetenciájának teljes megvonása. A humán döntési pontok kiiktatása és azok automatizmusokkal történő felváltása az elmúlt évek egyik olyan jelentős törekvése, amelytől a korrupció visszaszorítását várják. Ezeket a várakozásokat a kutatások részben igazolták; kimutatták például, hogy a fejlettebb gazdaságok körében az információs technológiai és e-kormányzati rendszerek használata pozitív kapcsolatban van a korrupció visszaszorulásával (Mistry-Jalal 2012; Linhartová 2017). A tapasztalatok ugyanakkor arra is rámutatnak, hogy a döntési kompetencia teljes elvonása a modern államigazgatásban elképzelhetetlen, az jelentős hatékonytalansághoz vezet (Kwon 2012), a bürokrácia túlszabályozása, bénítása pedig nem a korrupció kontrolljaként, hanem korrupciót fokozó tényezőként is hathat (Anechiarico-Jacobs 1996).

\section{Korrupció, szervezeti integritás, kockázatok kezelése}

A hivatali korrupcióval szembeni ex post facto, invesztigatív és represszív eszközök limitáltsága irányította rá a figyelmet a korrupciót megelőzni képes szervezeti tulajdonságok vizsgálatára, amelyet összefoglalóan az integritás név alatt ismerünk. A latin eredetű kifejezés olyasvalakit vagy valamit jelöl, aki vagy ami romlatlan, sértetlen, feddhetetlen (Báger 2013). Az integritás egy személy vagy szervezet azon minőségi ismérve, amely a szervezet vagy a társadalom tagjai által elfogadott morális értékek, standardok szerinti müködés minőségére utal (Kolthoff 2007). Szervezetirányítási szempontból az integritás azt jelenti, hogy a szervezetnek pozitív, a társadalmi elvárásokkal összhangban álló, szilárd értékrendje van (Domokos et al. 2016).

Az integritás fogalma az ÁSZ integritásfelmérésében (lásd A vizsgálat módszertana) egy további, a fentieknél specifikusabb értelemben használatos: integritással bíró szervezetről beszélünk, amennyiben az a tevékenységében, jogállásában rejlő korrupciós veszélyekkel szemben megfelelő kontrollokkal rendelkezik. Az integritás egyszerre jelenti a szervezet célkitűzéseknek megfelelő működését, valamint korrupcióval szembeni védekezőképességet. Az ilyen szervezeteknél arra számíthatunk, hogy csalás, vesztegetés nemigen fordul elő. Ám ez nem zárja ki azt, hogy előfordulhatnak nem szándékos számviteli pontatlanságok, vagy akár hiányos lehet a tűzvédelmi szabályozás (Pulay 2014). Az ebben a megközelítésben megjelenő „integritási kockázat” nem immanensen „rossz” és kiküszöbölendő. A közszférának szüksége van beszerzésekre, hogy múködhessen, a közigazgatás múködésében szükség van arra, hogy annak tagjai döntési kompetenciával is bírva az állampolgárokat jogokkal és kötelezettségekkel ruházhassák föl. A szervezeti integritásra fókuszáló megközelítésben a korrupciós veszély mérséklésének elsődleges útja tehát a kontrollkiépítettség fokozása.

Jelen kutatás arra keresi a választ, hogy az integritásfelmérés eredményei alapján mi mondható el a hazai közhatalmi tevékenységet folytató intézmények integri- 
tási helyzetéről, a közhatalmi tevékenységet jellemző kulcskockázatok és kontrollok viszonyáról, hogy a kontrollok szintje hol marad el és mely területeken haladja meg a kockázatok által indokolt szintet.

\section{A vizsgálat módszertana}

Az ÁSZ 2011 óta évente elvégzi a közszféra intézményei körében az integritásfelmérést. Az országos adatfelvételre - az ÁSZ Integritás portáljáról letölthető elektronikus kérdőív ${ }^{1}$ alkalmazásával - 2017-ben már hetedik alkalommal került sor. A 2017-es felmérés elsősorban a 2016. január 1-je és 2016. december 31-i időszakot öleli fel, míg egyes kérdések az elmúlt három évre kérdeznek rá, amelyek a 2014. január 1-je és 2016. december 31-e közötti időszakot fedik le.

Elsődleges célunk a közszférába tartozó intézmények korrupciós kockázati jellemzőinek feltárása volt. A közszféra intézményei korrupciós kockázatainak és a kapcsolódó kontrollok kiépítettségének meghatározására egy 16 kérdéscsoportból álló kérdőívet használtunk fel, amely összesen 169 kérdésből áll. ${ }^{2}$ Ugyanazt az egységes kérdőívet töltötték ki az eltérő jogállású és eltérő intézménycsoportba sorolt intézmények. A kérdőívet és az ahhoz tartozó kitöltési útmutatót a hatályos jogszabályokkal való összhang érdekében felülvizsgáltuk.

A kérdőívre adott válaszok alapján - előzetesen definiált algoritmus segítségével - az informatikai adatfelvételi és adatfeldolgozó rendszer az intézmények korrupciós érintettségére vonatkozóan százalékos formában kifejezett indexet számol. Ezek a következők (Pulay et al. 2014):

Az Eredendő Veszélyeztetettségi Tényezők (EVT) index a szervezetek jogállásától és feladatköreitől függő eredendő veszélyeztetettség összetevőit teszi mérhetővé. Ezt olyan tényezők határozzák meg, melyek alakítása az alapító szerv jogalkotási hatáskörébe tartozik, így például a hatósági jogalkalmazás, a (jogi) szabályozás vagy a különféle (oktatási, egészségügyi, szociális és kulturális) közszolgáltatások nyújtása.

A Korrupciós Veszélyeket Növelő Tényezők (KVNT) index az egyes intézmények napi múködésétől függő - az eredendő veszélyeztetettséget növelő - összetevőket jeleníti meg. Ez leképezi a költségvetési szervezetek jogi/intézményi környezetének jellemzőit, múködésük kiszámíthatóságát, stabilitását, továbbá az intézmények múködtetése során jelentkező - alapvetően a mindenkori menedzsment döntéseitől befolyásolt - olyan változó tényezőket, mint a stratégiai célok meghatározása, a

1 A kérdőív 155 kérdést tartalmazó verziója (2019. április 20.) letölthető innen (45. oldaltól): http://integritas.asz.hu/uploads/files/ asz_sugo-kerdoivB5_last\%20(nyomdai).pdf. Utolsó letöltés: 2019. április 20.

2 A 169 kérdés nagyobb részét dichotóm (igen-nem) kérdések alkotják, az intézményi sajátosságokhoz való igazodás miatt egyes esetekben „nem értelmezhető” válaszopcióval kiegészítve. Az említettek mellett feleletválasztós kérdések is megtalálhatók a kérdőív struktúrájában, melyek között vannak egy, illetőleg több válasz megjelölését is lehetővé tevő kérdések. A harmadik kérdéscsoportba tartoznak azok a kérdések, amelyeknél a kitöltő szervezet maga adja meg a választ egy-egy számadat beírásával. A kérdőív kitöltése önkéntes alapon müködött. Azokat az eseteket, ahol a válaszadók nem adtak meg adatokat vagy nem adtak értékelhető választ, hiányos adatként kezeltük a rendszerben. 
szervezeti struktúra és kultúra alakítása, valamint a személyi és költségvetési erőforrásokkal, illetve a közbeszerzésekkel való gazdálkodás.

A harmadik - a Kockázatokat Mérséklő Kontrollok Tényezője (KMKT) - index azt tükrözi, hogy az adott szervezetnél léteznek-e intézményesült kontrollok, illetőleg, hogy ezek ténylegesen működnek-e, betöltik-e rendeltetésüket. Ehhez az indexhez további olyan faktorok tartoznak, mint a szervezet belső szabályozása, a külső és belső ellenőrzés, valamint az egyéb integritáskontrollok: etikai követelmények meghatározása, összeférhetetlenségi helyzetek kezelése, a bejelentések, panaszok kezelése, rendszeres kockázatelemzés és tudatos stratégiai menedzsment.

Az alapsokaságot 12870 közintézmény képezte, melyből azokat kértük fel válaszadásra, amelyek bizonyos mértékủ hivatali önállósággal rendelkeznek. Kimaradtak így az adatfelvételból a helyi nemzetiségi önkormányzatok, mivel ezek gazdálkodását a jegyző törvényességi felügyelete mellett a helyi önkormányzat hivatala végzi. Az adatfelvétel során összesen 10245 közintézményt kértünk fel válaszadásra, amelyből 3346 küldött vissza kiértékelhető kérdőívet (2. ábra). Ebből a 3346 intézményből összesen 1413 intézmény válaszolt úgy, hogy szervezetük rendelkezik egyedi hatósági jogkörökkel, illetve folytat jogalkalmazást. A mintánk nem tekinthető reprezentatívnak, így a bemutatott eredményeket nem lehet a közszféra intézményeinek összességére kivetíteni. ${ }^{3} \mathrm{Az}$ alapsokaságban vannak olyan intézménycsoportok, amelyben a válaszadó intézmények köre és az alapsokaság intézménycsoporti szegmense teljes mértékben lefedik egymást (Kormányzati szervezetek, Területi igazgatási szervezetek). Az ezen intézménytípusokat érintő változásokról teljes képet kaphatunk. A mi vizsgálatunk szempontjából ez azért lényeges, mert ez a két intézménycsoport hatósági jogkörrel rendelkezik.

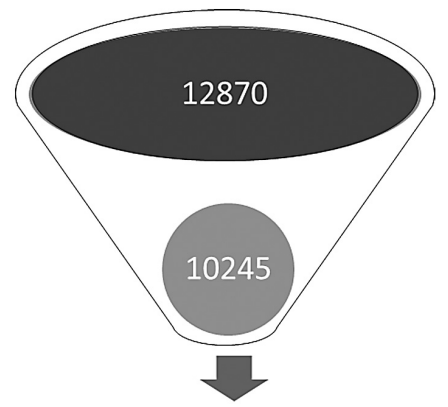

3346

3 Az alapsokaságra és a mintára vonatkozó adatokat lásd az 1. sz. mellékletben. 
Összesen tehát 1413 intézmény nyilatkozott úgy, hogy rendelkezik hatósági jogkörrel, azaz közhatalommal. A 15 intézménycsoportot megvizsgálva látható (1. táblázat), hogy a válaszadó intézmények közül van olyan, ahol az adott intézménycsoportban (szinte) minden válaszadó rendelkezik hatósági jogkörrel (pl. helyi önkormányzat, területi igazgatási szervek), és vannak olyan csoportok, ahol egyáltalán nem jellemző ennek megléte, vagy csak elenyésző mértékben. Az egyes intézménycsoportokon belül bizonyos dimenzióikat tekintve eltérő jogállású intézmények is szerepelhetnek. Például egyes egészségügyi intézmények végeznek ellenőrzést, engedélyezést vagy más hatósági tevékenységet, míg mások nem rendelkeznek ilyen jellegü közhatalmi funkcióval. Egyes intézménycsoportoknál, például az önkormányzatok esetében, a látszólag azonos jogállás ellenére lehetnek különbségek a feladatellátásról szóló válaszadás tekintetében, mivel a kisebb önkormányzatok egyes hatósági típusú feladatokat is más önkormányzattokkal közös polgármesteri hivatalok útján látnak el. Ugyanakkor vannak olyan intézménytípusok, amelyek kizárólag közszolgáltatást nyújtanak, hatósági tevékenységet nem végeznek, mégis néhány válaszadó igennel válaszolt az erre vonatkozó kérdésre - ilyenek voltak például az óvodák. A kockázatok és kontrollok együttmozgásánál csak a hatósági jogkörrel nagy arányban rendelkezőket vesszük figyelembe.

1. táblázat: A közhatalmi feladatot ellátó közintézmények száma (db) a válaszadók közül és az egyes intézménycsoporton belüli aránya (\%)

\begin{tabular}{l|c}
\multicolumn{1}{c|}{ Intézménycsoport } & $\begin{array}{c}\text { Hatósági jogkörrel rendelkező intézmények } \\
\text { száma, db (\%) }\end{array}$ \\
\hline Általános és középfokú oktatás & $0(0)$ \\
\hline Egészségügyi intézmények & $2(2)$ \\
\hline Egyéb - igazgatási tevékenység & $20(11)$ \\
\hline Egyéb tevékenységek & $5(19)$ \\
\hline Felsőoktatás & $4(18)$ \\
\hline Független államhatalmi szervek & $3(30)$ \\
\hline Helyi önkormányzat & $1265(80)$ \\
\hline Igazságszolgáltatás & $12(44)$ \\
\hline Kormányzati szervek & $8(100)$ \\
\hline Kulturális intézmények & $2(1)$ \\
\hline Óvoda, bölcsőde & $10(2)$ \\
\hline Rend- és honvédelem & $57(48)$ \\
\hline Szociális ellátó intézmények & $5(1)$ \\
\hline Területi igazgatási szervek & $20(100)$ \\
\hline Tudományos kutatás, fejlesztés & $0(0)$ \\
\hline Összesen & $1413(42)$
\end{tabular}

Mivel tanulmányunk a hatósági jogkörrel rendelkező intézményekre koncentrál, illetve azok kockázatainak és kontrolljainak feltárására, ezért a kérdőív alapján beazonosítottuk a közhatalmi tevékenységhez kapcsolódó kérdéseket. A kérdések beazonosítása után a hatósági jogkörhöz tartozó kockázatok és kontrollok alapján 
két összevont indexet hoztunk létre, amelyek a hatósági jogkör kockázatait, illetve a hatósági jogkör kontrolljait mutatják be. Az indexek képzése az integritásfelmérés kérdőívéhez tartozó algoritmus alapján történő pontozás átlagolásával történt, melyet aztán normalizáltunk. Az így kapott értékeket megszoroztuk százzal, így egy százalékban kifejezett mutatószámot kaptunk. Elemzésünk során az így kapott értékeket prezentáljuk az Állami Számvevőszék 2017. évi integritáselemzése alapján (Németh et al. 2017).

\section{A hatósági tevékenység végzésével összefüggő kulcskockáza- tok és kontrollok}

Kutatásunk során megvizsgáltuk, hogy a hatósági tevékenységet folytató intézmények a kiválasztott kockázati tényezők vonatkozásában milyen összevont kockázati indexértékkel rendelkeznek, illetve ehhez kapcsolódóan kockázataikat miképpen mérséklik a megfelelő kontrollokkal. Kutatásunk a bevezetésben bemutatott szakirodalommal összhangban azt tekintette kiindulópontnak, hogy a hatósági tevékenység gyakorlása során a döntési diszkréció hordoz kiemelt integritási veszélyt. Ezt a kérdőív mérlegelési jogkörre, valamint a méltányosság gyakorlására, engedélyezési, ellenőrzési, szabálysértési, illetve szakhatósági véleményezésre vonatkozó kérdései útján azonosítottuk be. Az egyedi elbírálási lehetőséget biztosító jogkörök ellensúlyaként a külső befolyásolás kontrolljai állíthatók szembe. Az integritásfelmérés kérdőívében ilyenek a mérlegelési szempontok megismerhetősége, az ajándékozási szabályzat jelenléte, a vagyonnyilatkozat tételére vonatkozó kérdések.

\section{Hatósági tevékenység: kockázatok és kontrollok}

Az adatszolgáltató intézmények közül legnagyobb arányban a területi igazgatási szervek, kormányzati szervek, valamint a helyi önkormányzatok rendelkeznek hatósági jogkörrel. A hatósági tevékenység mint kockázat hat intézménycsoport esetében (alapfokú oktatás, egészségügy, szociális ágazat, kulturális intézmények, óvodák-bölcsődék, tudományos kutatás-fejlesztés intézménycsoport) kevéssé jellemző, 10\% alatti.

Kutatásunk során a hatósági tevékenység végzésével összefüggésben hat kockázati veszélyeztetettséget növelő tényezőt, illetve tíz kockázatokat mérséklő kontrollt azonosítottunk (2. táblázat). A kontrolltényezők részben támogatják a folyamatok átláthatóságát, objektivitását és befolyásmentességét, illetve segítik az integritást sértő tevékenység feltárását. A munkahelyi rotáció például hatósági ellenőrzés esetén azért jelent integritáskontrollt, mert megakadályozza, hogy az ellenőrzést végző személy hosszabb időn keresztül ugyanazon a területen végezze a munkáját. Utóbbi esetben ugyanis fennáll a veszélye, hogy az ellenőr és az ellenőrzött között személyes kapcsolat alakul ki, ami csökkenti az eljárás objektivitását, befolyásmentességét. A kockázatokat, illetve a kontrollokat a hatósági tevékenységet folytató intézményeknél intézménycsoportonkénti bontásban is kimutattuk (3. és 4. ábra). 
2. táblázat: A hatósági jogkörhöz kapcsolódó kockázatok és kontrollok

\begin{tabular}{|c|c|c|c|}
\hline $\begin{array}{l}\text { KÉRDÉS- } \\
\text { SZÁM }\end{array}$ & KÉRDÉS & INDEX & TíPUS \\
\hline 30 & $\begin{array}{c}\text { Szervezetüknek vannak-e egyedi hatósági jogkörei, foly- } \\
\text { tat-e hatósági jogalkalmazást? }\end{array}$ & EVT & alapkérdés \\
\hline 31 & $\begin{array}{l}\text { Ha vannak egyedi hatósági jogkörei vagy hatósági jogalkal- } \\
\text { mazást folytat, ezek között vannak-e engedélyezési típusú } \\
\text { hatáskörök? }\end{array}$ & KVNT & \multirow{6}{*}{ kockázati index } \\
\hline 33 & $\begin{array}{c}\text { Ha Szervezetüknek vannak egyedi hatósági jogkörei vagy } \\
\text { hatósági jogalkalmazást folytat, ezek között vannak-e } \\
\text { szabálysértési hatósági hatáskörök? }\end{array}$ & KVNT & \\
\hline 36 & $\begin{array}{c}\text { Ha Szervezetüknek vannak egyedi hatósági jogkörei vagy } \\
\text { hatósági jogalkalmazást folytat, Szervezetük végez-e ható- } \\
\text { sági ellenőrzéseket? }\end{array}$ & KVNT & \\
\hline 37 & $\begin{array}{l}\text { Ha Szervezetüknek vannak egyedi hatósági jogkörei vagy } \\
\text { hatósági jogalkalmazást folytat, Szervezetük végez-e szak- } \\
\text { hatósági véleményezést? }\end{array}$ & KVNT & \\
\hline 39 & $\begin{array}{l}\text { Ha Szervezetüknek vannak egyedi hatósági jogkörei vagy } \\
\text { hatósági jogalkalmazást folytat, Szervezetüknek vannak-e } \\
\text { mérlegelésen alapuló hatósági hatáskörei? }\end{array}$ & KVNT & \\
\hline 41 & $\begin{array}{c}\text { Ha Szervezetüknek vannak egyedi hatósági jogkörei vagy } \\
\text { hatósági jogalkalmazást folytat, az azok gyakorlása során a } \\
\text { szervezet szokott-e méltányosságot alkalmazni? }\end{array}$ & KVNT & \\
\hline 43 & $\begin{array}{c}\text { Ha Szervezetük szokott méltányosságot alkalmazni, a ha- } \\
\text { tósági mérlegelés szempontjai elöre megismerhetők-e az } \\
\text { ügyfelek számára? }\end{array}$ & KMKT & \multirow{10}{*}{$\begin{array}{l}\text { kontroll } \\
\text { index }\end{array}$} \\
\hline 109 & $\begin{array}{c}\text { Jelöljék, ha a Szervezetnél léteznek az alábbi személyekkel } \\
\text { való kapcsolattartásra vonatkozó szabályok! A) gazdasági } \\
\text { szereplők (for profit szektor), B) politikusok (választott } \\
\text { képviselők), C) más állami/önkormányzati szervek vezető } \\
\text { tisztviselői. }\end{array}$ & KMKT & \\
\hline 119 & $\begin{array}{l}\begin{array}{l}\text { Szervezetük milyen formában szabályozza az összeférhetet- } \\
\text { lenség kérdéskörét? }\end{array} \\
\end{array}$ & KMKT & \\
\hline 120 & $\begin{array}{c}\text { Szervezetük belső szabályozása kötelezővé teszi-e a mun- } \\
\text { katársaknak, hogy nyilatkozzanak gazdasági vagy - a } \\
\text { Szervezet tevékenysége szempontjából releváns - egyéb } \\
\text { érdekeltségeikről? }\end{array}$ & KMKT & \\
\hline 121 & $\begin{array}{l}\text { Szervezetükön belül szabályozva vannak-e a különféle aján- } \\
\text { dékok, meghívások, utaztatás elfogadásának feltételei? }\end{array}$ & KMKT & \\
\hline 122 & $\begin{array}{c}\text { Szervezetüknek van-e belső szabályzata a Szervezeten belü- } \\
\text { li közérdekű bejelentők védelmére? }\end{array}$ & KMKT & \\
\hline 133 & $\begin{array}{l}\text { Ha vannak vagyonnyilatkozat-tételre kötelezett személyek, } \\
\text { pontosan meghatározott-e a Szervezetben a vagyonnyilat- } \\
\text { kozat-tételre köteles személyek köre? }\end{array}$ & KMKT & \\
\hline 154 & $\begin{array}{l}\text { Szervezetük müködtet-e külső (a szervezeten kívülröl érke- } \\
\text { ző) panaszokat kezelő rendszert? }\end{array}$ & KMKT & \\
\hline 155 & $\begin{array}{l}\text { Szervezetük müködtet-e közérdekü bejelentéseket kezelő } \\
\text { rendszert? }\end{array}$ & KMKT & \\
\hline 159 & Működik-e Szervezetüknél munkahelyi rotáció? & KMKT & \\
\hline
\end{tabular}

A hatósági jogkörrel rendelkező intézmények körében hat kulcskockázatot azonosítottunk, amelyek jelentős kockázatot hordoznak integritási szempontból. A hatósági jogkörrel rendelkező szervezeteknél a korrupciós kockázatok vonatkozásában elsősorban az egyedi mérlegelésen alapuló döntési jogkör és méltányosság gyakorlása igényel figyelmet. További kockázat, ha a szervezetek a hatósági tevékenységük körében engedélyezési, ellenőrzési, szabálysértési, illetve szakhatósági véleményezést gyakorolnak. 
A kutatási eredmények szerint az adatszolgáltató szervezetek közül 1413 intézmény (42\%) végez hatósági tevékenységet, ezen intézmények 83 százaléka rendelkezik engedélyezési típusú hatáskörrel, kétharmaduk hatósági ellenőrzéseket végez, és több mint felük szakhatósági véleményezéseket készít. A hatósági jogalkalmazást folytató intézmények többsége nyilatkozott arról, hogy van mérlegelésen alapuló jogköre (78\%), illetve 71 százaléka méltányosságot alkalmaz a jogkörgyakorlása során. A méltányosságot a jogszabályok kivételes lehetőségként biztosítják, ennek fényében nagy kockázatot jelez az, hogy a hatósági jogalkalmazást végzők jelentős része számolt be arról, hogy alkalmazott már méltányosságot. Nem zárhatjuk ki, hogy olyan intézmények is alkalmaztak méltányosságot, amelyek erre nem rendelkeztek felhatalmazással.

A hatósági jogalkalmazás területén legmagasabb összevont kockázati indexszel a területi igazgatási szervek rendelkeznek, magas veszélyeztetettséget mértünk még a kormányhivataloknál, a kormányzati szerveknél, az egészségügyi intézményeknél, a független állami szerveknél, a rend és honvédelem intézményeinél és a helyi önkormányzatoknál. Ezek többsége rendelkezik engedélyezési, ellenőrzési, szakhatósági véleményezési, illetve mérlegelésen alapuló jogkörrel, valamint méltányosságot alkalmaz a jogkörgyakorlása során.

A hatósági jogkörrel rendelkező egészségügyi és területi igazgatási szervezetek szinte mindegyike rendelkezik engedélyezési, szakhatósági véleményezési jogkörrel. Fenti jogkörök tekintetében a rend- és honvédelem, valamint a kormányzati szervezetek csoportja jelentős, míg a helyi önkormányzatok átlagos kockázati szintet mutatnak (3. ábra).

A szabálysértéshez kapcsolódó hatósági jogkörrel csupán a válaszadók 22 százaléka rendelkezik. A területi igazgatási szervezetek, a rend- és honvédelem, valamint az igazságszolgáltatás nagy arányban végeznek ilyen jellegű tevékenységeket, ami megnöveli integritási kockázatukat. 


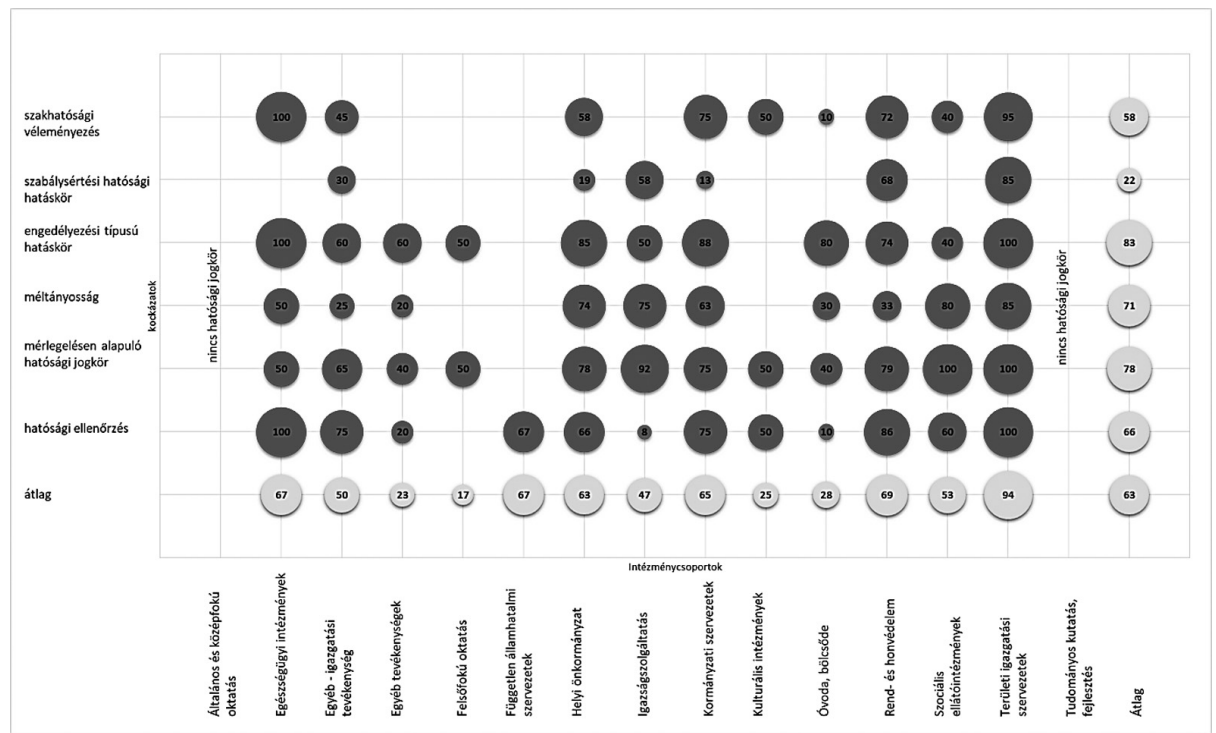

Hazánkban a hatósági tevékenységhez kapcsolódó kontrollok közül a külső és belső bejelentők védelme, a munkahelyi rotáció alkalmazása és a kapcsolattartási szabályok nincsenek megfelelően kiépítve. A hatósági jogkört alkalmazó intézmények ugyanakkor magas arányban építették ki az alábbi kontrollokat: összeférhetetlenség szabályozása, vagyonnyilatkozat-tételi, illetve gazdasági érdekeltséggel kapcsolatos nyilatkozattételi kötelezettség.

A mérlegelési hatáskör kiemelt integritási veszélyeztetettséget hordoz, azaz növeli a korrupciós helyzetek kialakulásának kockázatát. Az integritási kockázatot mérsékli, az átláthatóságot és a közbizalmat növeli, ha a mérlegelés szempontjai megismerhetők az ügyfelek számára. A hazai közintézmények gyakorlatában a szempontok megismerhetősége jellemző, ez a kontroll az érintett intézmények 62 százalékánál megfelelően kiépített.

A hatósági jogkörrel rendelkező intézmények kockázataihoz felsorakoztattuk az egyes kulcskontrollokat, amelyek a 3. és 4. ábrán láthatók. A hatósági döntések szempontjai a területi igazgatási szervezetek 80 százalékánál megismerhetőek. Ez a szint még így is alacsonynak mondható, hiszen az összes, hatósági jogkörrel rendelkező, ebbe az intézménycsoportba tartozó szervezetnél a mérlegelési jogkör kockázatként jelenik meg.

A szervezeten belüli bejelentők védelme alacsony kiépítettségű, hiszen az összes válaszadó 28 százalékánál van jelen ez a kontrolleszköz, hasonlóan a panaszok kezeléséhez és a belső szabályzathoz, illetve a szervezeten belüli bejelentők védelméhez. Ezek a kontrollok nagy szerepet játszanak a hatósági jogkörhöz kapcsolódó szakhatósági véleményezés, szabálysértési, engedélyezési és mérlegelésen alapuló jogkörök visszaéléseinek feltárásában. Fontos, hogy az állampolgárok és a szervezeten belüli személyek is bejelentést és panaszt tudjanak tenni, amennyiben rendellenes tevé- 
kenységgel, integritást sértő magatartással találkoznak. E három tényező kiépítettségében legrosszabbul a felsőfokú oktatás szerepel, ahol abszolút nem találhatóak meg ezek a kontrollok, valamint az óvoda, bölcsőde, ahol csupán az intézmények 20 százaléka rendelkezik a szükséges kontrollokkal.

A hatósági jogkör gyakorlása során nagy szerepe van az ajándékok, meghívások, utaztatás elfogadása szabályozásának, mivel ezzel a korrupciógyanús befolyásolási kísérletek kiszűrhetők. Az eredmények azt mutatják, hogy ez a kontroll bizonyos intézménycsoportokban jelentős mértékben hiányzik, pl. a felsőfokú oktatásban, helyi önkormányzatoknál, óvodákban, bölcsődékben és a szociális ellátóintézményekben. A munkahelyi rotáció szintén alacsonyan elterjedt a hatósági jogkörhöz kapcsolódó intézményeknél, ugyanakkor a vagyonnyilatkozat tétele az egyéb tevékenységek csoportjában jelez csak problémát. Hasonló képet mutat az egyéb érdekeltségekről való nyilatkozattétel is, amely szintén az egyéb tevékenységeknél, helyi önkormányzatoknál utalhat az integritáskontroll hiányára.

A kapcsolattartási szabályok kialakítása, mint kontroll, nem terjedt el az elvárható mértékben, hiszen a területi igazgatási szervezetek és az igazságszolgáltatás intézménycsoportján kívül alacsony mértékú a kiépítettsége.

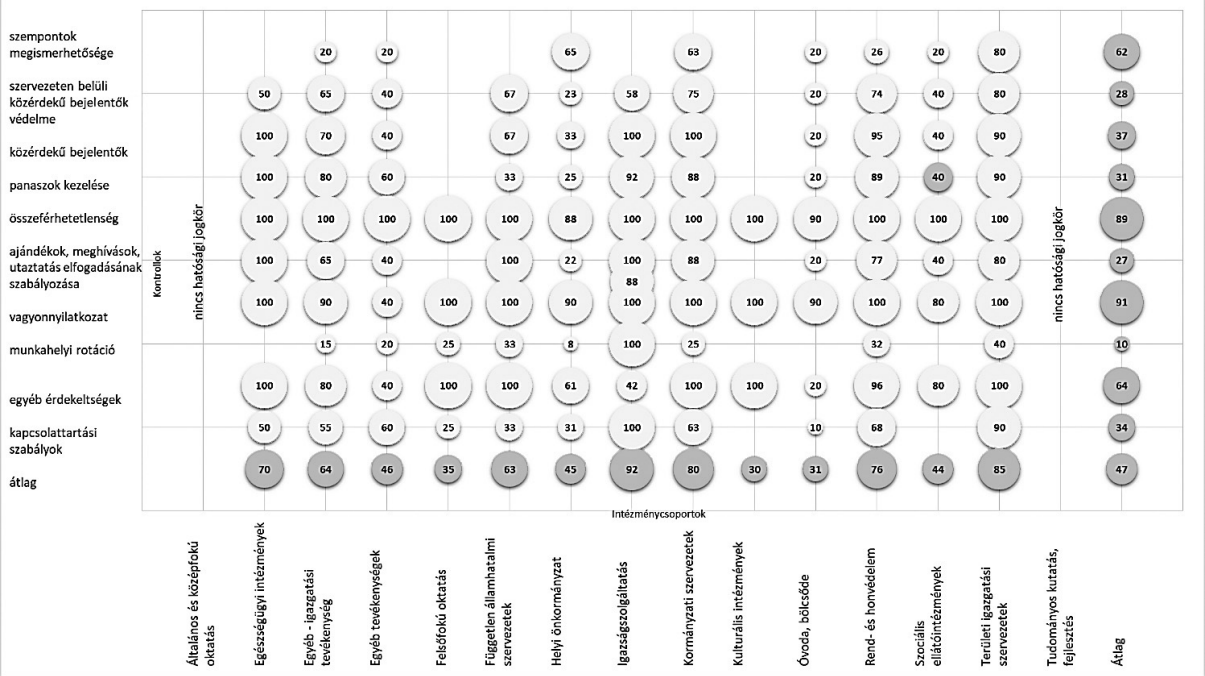

\section{Hatósági jogkörök: kockázatok és kontrollok viszonya}

Megvizsgáltuk, hogy a hatósági jogkörrel kapcsolatos kockázatok mérséklésére milyen mértékben építettek ki kontrollokat az egyes intézménycsoportok.

Az 5. ábrán látható, hogy az intézmények hány százaléka rendelkezik hatósági jogkörrel az egyes intézménycsoportokban (szürke oszlop), illetve hogy ez a kör 
milyen hatósági jogkörrel kapcsolatos kockázati indexszel és kontrollindexszel rendelkezik. Hasonlóan az eddigiekhez, az indexeket a hatósági jogkörhöz kapcsolódó kockázatokból és kontrollokból a kérdőív algoritmusa alapján határoztuk meg, majd normalizáltuk. Megállapítottuk, hogy azoknál az intézménycsoportoknál, amelyek körében 10 százaléknál magasabb arányban rendelkeznek az intézmények hatósági jogkörrel, a két index közti korreláció 0,58, ami közepes, pozitív kapcsolatot jelez. Mindez azt jelenti, hogy nem mindenhol társul nagyobb kontrollkiépítettség a nagyobb kockázatokhoz (pl. helyi önkormányzatok esetében nem). A robusztusság vizsgálatára a korrelációkat kiszámítottuk egy-egy intézménycsoport kockázati és kontrollindex-értékpárjainak kihagyásával. A vizsgálat során azt kaptuk, hogy nincs olyan intézménycsoport, amely outlierként viselkedne, azaz amelynek elhagyása érzékenyen befolyásolná a kapcsolatot, hiszen a korrelációk 0,51 és 0,69-es értékek közé esnek (2. sz. melléklet).

A kormányhivatalok és a kormányzati szervek magas kockázati indexértékkel rendelkeznek, ugyanakkor kontrollkiépítettségük is az átlagnál magasabb szintü. A helyi önkormányzatok átlagosnál magasabb kockázati szintjéhez viszont átlag alatti kontrollindex társul, ami abból adódik, hogy az önkormányzatok kevesebb mint egyharmada rendelkezik csak közérdekű bejelentések, panaszok kezelése, ajándékozás, külső kapcsolattartás szabályozásával. Az igazságszolgáltatás szerveinél éppen fordítva, az alacsonyabb kockázati indexhez magas kontrollindex kapcsolódik.

5. ábra: A hatósági jogkörhöz kapcsolódó kockázati és kontrollindex átlagai intézménycsoportonként (\%)

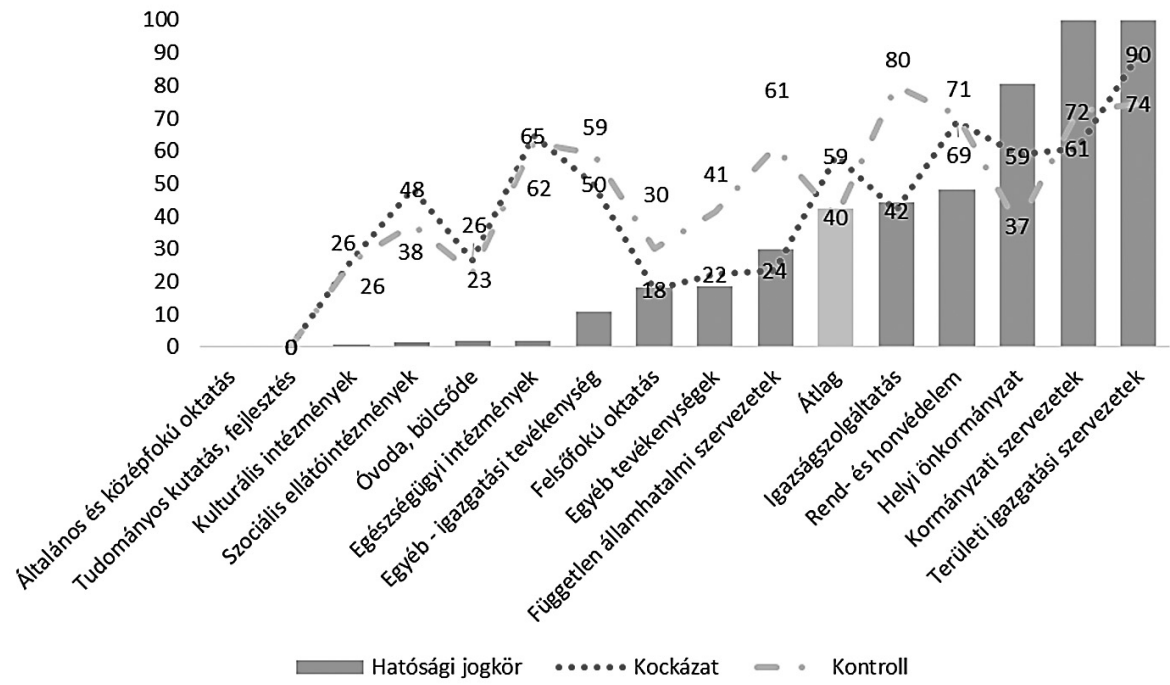


A hatósági jogkörhöz tartozó kockázatok kontrollokkal való lefedettségének pontosabb beazonosítása érdekében az intézményeket az összevont kockázati indexértékük alapján 3 csoportba soroltuk (alacsony: 0-33,3\%, közepes: 33,4-66,6\%, magas: 66,7-100\%), majd megvizsgáltuk, hogy a kontrollindexek követik-e a kockázatosság mértékét. A hatósági tevékenységet folytató intézmények 17 százaléka alacsony, 22 százaléka közepes, 61 százaléka magas kockázatiindexérték-tartományba esik (6. ábra). A kutatási eredmények azt mutatják, hogy különböző kockázati szinttel rendelkező intézmények kontrollszintjei nem mutatnak különbségeket. Akár magasabb, akár alacsonyabb a kockázati szint, az integritáskontrollok kiépítettsége közel azonos. Mindhárom csoport esetében az átlagos kontrollindex-mutató 40 százalék körüli értéket mutat.

6. ábra: Az alacsony, közepes és magas kockázati szintek szerinti kontroll lefedettség a válaszadók körében (\%)

90

80

70

60

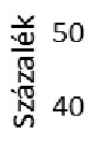

30

20

10

50

30 $n=238$

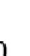

40 40

0

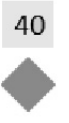

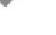

16

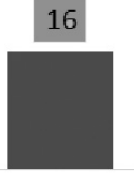

$n=313$

(1)

45

alacsony kockázattal rendelkezők

közepes kockázati szinttel rendelkezók

Kockázati szintek $\mathrm{n}=862$

78

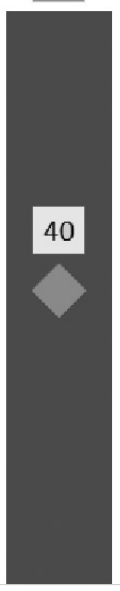

magas kockázati szinttel rendelkezők

- Kockázat * Kontroll

A mérlegelési hatáskör kiemelt integritási veszélyeztetettséget hordoz, azaz növeli a korrupciós helyzetek kialakulásának kockázatát, mivel a döntéshozó saját belátása szerint határozhat. Az integritási kockázatot mérsékli, az átláthatóságot növeli, ha a mérlegelés szempontjai megismerhetők az ügyfelek számára. 
A mérlegelésen alapuló hatósági jogkör mint kockázati tényező valamennyi intézménycsoportnál jelentkezik, legmagasabb arányban a területi igazgatási szerveknél (100\%), a szociális ellátó intézményeknél (100\%), az igazságszolgáltatás szerveinél (92\%), a helyi önkormányzatoknál (79\%) és a rend- és honvédelemnél (79\%) fordul elő. Ezeknél az intézménycsoportoknál a kockázati szintet tovább növeli, hogy a mérlegelési jogkör mellett magas arányban van méltányosság gyakorlására lehetőségük (7. ábra).

A hazai közintézmények gyakorlatában igen jelentős kockázatot jelent a méltányosság gyakorlása, a szempontok megismerhetősége azonban szintén jellemző, így a kockázat jelentősen mérsékelt. Az átláthatóság ezenkívül növeli az állampolgári bizalmat.

\section{7. ábra: Méltányosság gyakorlása és a mérlegelési szempontok megismerhetősége (\%)}

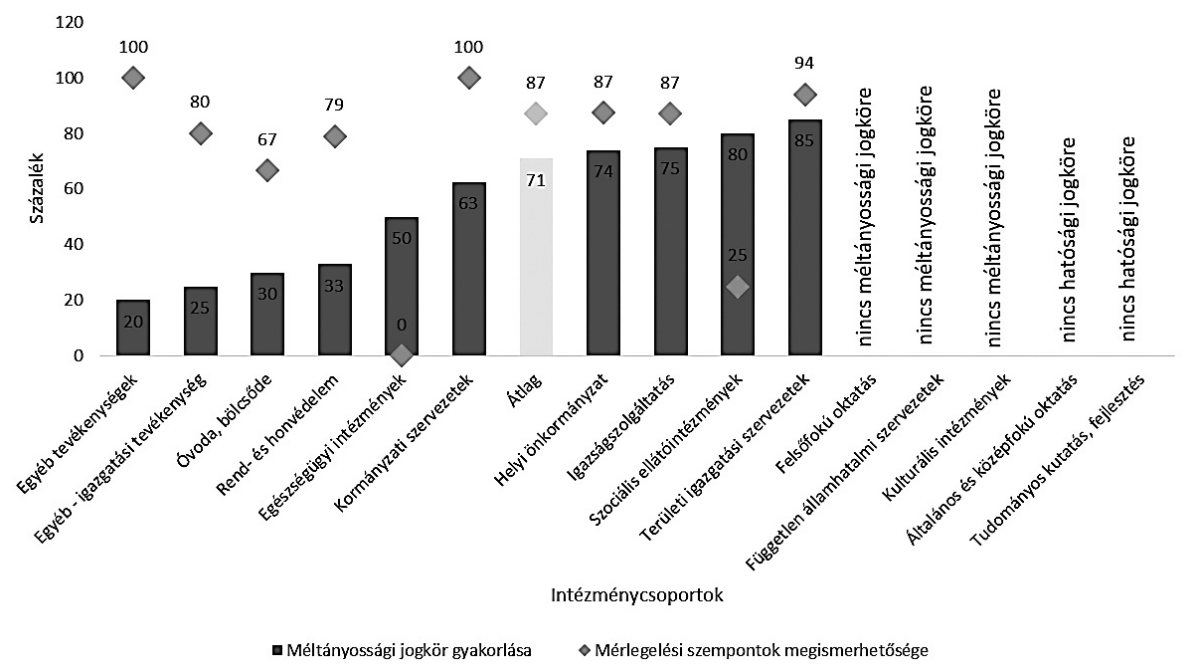

\section{Következtetések}

$\mathrm{Az}$, hogy az állami szerv igazolványokat állítson ki, engedélyt, szakhatósági véleményt bocsásson ki, nélkülözhetetlen mind a magánszemélyek, mind a gazdasági szereplők mindennapi életéhez, tevékenységéhez. Ilyen típusú feladatokat a válaszadó intézmények kétötöde lát el, elsősorban az önkormányzatok, a kormányzat és a területi igazgatás szervezetei. A hatósági jogkörökben rejlő korrupciós veszély hazánkban megfelelő mértékben tudatosult. Az állami szabályozás számol azzal, hogy az ilyen tevékenység végzésére feljogosított szervezetek, az ezekben dolgozó közhivatalnokok erős korrupciós érdekeltséggel néznek szembe, ezért az ilyen tevékenységre vonatkozó szabályozások hagyományosan szigorúak. 
Ezt az általános képet az integritásfelmérés eredményei is visszaigazolták: a hatósági tevékenységet folytató intézményeknél azt találtuk, hogy az eltérő kockázati szinttel (alacsony, közepes, magas) rendelkező intézmények kontrollszintjei nem mutatnak különbségeket. Akár magasabb, akár alacsonyabb a kockázati szint, a kontrollok kiépítettsége közel azonos. A hatósági jogköröket gyakorlók esetében a kontrollok ezen „rugalmatlansága” hol kontrollhiányt, hol pedig túlkontrolláltságot okoz. Ezzel ellentétben a közszféra egészét vizsgálva a magasabb kockázatokat általában követi a kontrollok erősebb kiépítettsége is. A kontrollok közel azonos szintje összefügghet a közhatalmat gyakorló intézmények részletes jogi szabályozottságával, vagyis bizonyos kontrollokat kötelező jelleggel ki kell építeniük függetlenül jogi státuszukból következő sajátos kockázati szintjüktől és mintázatuktól. Miközben a kötelező jogi szabályozás általában segíti a megfelelő kontrollszint biztosítását, az alacsony kockázati szintú, főleg kisebb intézmények esetén a túlzott kontrollnak megvannak a maga költségei. A kontrollok ugyanis többletmunkaterhet jelentenek, és ellene hathatnak a hasznos specializációnak.

A kormányhivatalok és a kormányzati szervek magas kockázatiindex-értékkel rendelkeznek, ugyanakkor kontrollkiépítettségük is az átlagnál magasabb szintú. Vannak olyan intézménycsoportok, ahol szükség lenne a kontrollok jobb kialakítására (rend- és honvédelem, területi igazgatási szervezetek, helyi önkormányzat, egészségügyi intézmények), mivel ezeknél a hatósági tevékenységekkel kapcsolatban mért kockázati indexek meghaladják a kontrollindexek szintjét. Ugyanakkor az igazságszolgáltatás szerveinél az alacsonyabb kockázati indexhez magas kontrollkiépítettség kapcsolódik.

A hatósági jogkörrel rendelkező szervezeteknél integritáskockázatot jelent az egyedi mérlegelésen alapuló döntési jogkör és méltányosság gyakorlása, az engedélyezési, ellenőrzési, szabálysértési, illetve szakhatósági véleményezési jogkör.

$\mathrm{Az}$ általánosan magas kontrollkiépítettség mellett a kutatás arra hívja fel a figyelmet, hogy a hatósági tevékenységhez kapcsolódó kontrollok közül a külső és a belső bejelentők védelme, a munkahelyi rotáció alkalmazása és a kapcsolattartási szabályok nincsenek megfelelően kiépítve. A hatósági tevékenység végzése során azért van szükség a munkatársak rotációjára, hogy az ugyanazokkal az ügyfelekkel való rendszeres találkozások ne alakítsanak ki olyan személyes viszonyt, amely veszélyeztetné az egyes hatósági döntések elfogulatlanságát, objektivitását, ami pedig csökkenti a társadalmi kockázatok és a közintézmények iránti bizalmatlanságot is.

\footnotetext{
Abstract: In 2017 the State Audit Office of Hungary assessed public institutions in terms of their integrity including their risks, as well as the level of controls mitigating those risks for the 7th time. In our study we analyse the integrity situation of institutions performing tasks of public authority on the basis of data from the 2017 survey. In the case of organisations exercising public authority the study identified several integrity risks, such as discretional decision-making authority, practicing equity, authorization and external control, as well as the powers to deal with administrative offences and issue administrative expert opinions. While, in general, the establishment of integrity controls is adequate,
} 
the protection of external and internal whistleblowers, workplace rotation and rules for contacts are not adequately established. Our results show that the control levels of institutions with different risk levels (high, medium, low) do not vary. Both in the case of higher or lower risk levels, the establishment of controls is almost identical. As regards those exercising public authority, such 'inflexibility' of controls results either in the lack of control or excessive control. Contrary to that, when examining the public sector as a whole, higher risks are generally accompanied with stronger establishment of controls.

Key words: integrity, public authority, risk, control

\section{Irodalom}

Anechiarico, F. - Jacobs, J. B. - Jacobs, J. B. (1996): The Pursuit of Absolute Integrity: How Corruption Control Makes Government Ineffective. University of Chicago Press.

Báger G. (2013): Korrupció: büntetés, integritás, kompetencia. Budapest: Akadémia Kiadó.

Čepas, A. - Dobryninas, A. (2016): Criminalization of corruption: Philosophical and legal facets. Problemos, 90(90): 20-30.

Domokos L. - Pulay Gy. - Szatmári J. - Gergely Sz. - Szabó Z. (2016): Az integritás kultúrájának meghonosítása a magyar közszférában. A jó kormányzás építőkövei - fókuszban a legfőbb pénzügyi ellenőrző szerv, az Állami Számvevőszék.

Economakis, G. - Rizopoulos, Y. - Sergakis, D. (2010): Patterns of corruption. Journal of Economics and Business, 13(2): 11-31.

Fazekas M. - Ficzere L. (2006): A magyar közigazgatási jog általános rész. Budapest: Osiris Kiadó.

Freille, S. - Haque, M. E. - Kneller, R. (2006): Federalism, decentralisation and corruption. Available at SSRN 951110, 6.

Ivanyna, M. - Moumouras, A. - Rangazas, P. (2016): The culture of corruption, tax evasion, and economic growth. Economic Inquiry, 54(1): 520-542.

Jávor I. (2008): A politikai korrupció szervezeti struktúrája. Egy lehetséges szervezetszociológiai modell. Társadalomkutatás, 26(3): 11-38.

Keller T. - Sik E. (2009): A korrupció észlelése, elfogadása és gyakorlata. TÁRKI Európai Társadalmi Jelentés; http://www.tarki.hu/hu/research/gazdkult/ gazdkult_keller_sik.pdf.

Klotz P. (2017): Az integritásszemlélet lehetőségei a korrupció elleni fellépésben, különös tekintettel a munkaköri kockázatok elemzésére- Doktori (PhD-)értekezés, Budapest; online: https://akk.uni-nke.hu/document/akk-uni-nke-hu/klotzpeter-phd-tezisfuzet.original.pdf.

Kolthoff, E. W. (2007): Ethics and New Public Management - Empirical Research into the Effects of Businesslike Government on Ethics and Integrity. New York: Legal Publisher.

Kőhalmi L. (2013): Joghistória villanások a magyar korrupció-büntetőjog történetéből. Jura, 19(1): 150-157.

Kwon, I. (2012): Motivation, discretion, and corruption. Journal of Public Administration Research and Theory, 24(3): 765-794. 
Linhartová, V. (2017). The role of e-government in mitigating corruption. Scientific papers of the university of pardubice. Series D, Faculty of Economics \& Administration, 25(40).

Mistry, J. J. - Jalal, A. (2012): An empirical analysis of the relationship between e-government and corruption. The International Journal of Digital Accounting Research, 12, 145-176.

Németh E. - Martus B. Sz. - Vargha B. T. - Gergely Sz. - Vasváriné Molnár J. Jakovác K. (2017): Elemzés a közszféra integritás helyzetéröl. Budapest: Állami Számvevőszék.

Németh E. - Vargha B. (2017): A magyar közintézmények integritása - Összehasonlító elemzés: 2013-2016. Integrity of Hungarian Public Sector Institutions Comparative analysis 2013-2016. Köz-Gazdaság, 2.

Németh E. - Martus B. - Vargha B. (2018): Közszolgáltatások integritáskockázatai és kontrolljai. Pénzügyi Szemle 63(2):161-181

Pulay Gy. - Szatmári J. - Kakatics L. - Szabó Z. Gy. (2014): Összefoglaló tanulmány a 2014. évi Integritás Felmérés eredményeiről. Budapest, Állami Számvevőszék. https://asz.hu/storage/files/files/Szakmai\%20kutat\%C3\%A1s/2014/integritas_ tanulmany_benyujtasra.pdf?ctid=744.

Pulay Gy. (2014): A korrupció megelőzése a szervezeti integritás megerősítése által. Pénzügyi Szemle, 59(2): 151-166.

Rubinstein, W. D. - Maravic, P. V. (2010): Max Weber, bureaucracy, and corruption. In Graaf - Maravic - Wagenaar (eds.): The Good Cause: Theoretical Perspectives on Corruption. https://nbn-resolving.org/urn:nbn:de:0168-ssoar-368768.

Søreide, T. (2014): Drivers of corruption: A brief review. The World Bank.

Søreide, T. - Rose-Ackerman, S. (2018): 7. Corruption in state administration. Research Handbook on Corporate Crime and Financial Misdealing, 195.

Szántó Z. - Tóth I. J. - Varga, S. (2011). A korrupció társadalmi és intézményi szerkezete. Szociológiai Szemle, 21(3): 61-82.

Tóth I. Gy. (2009): Bizalomhiány, normazavarok, igazságtalanságérzet és paternalizmus a magyar társadalom értékszerkezetében. A gazdasági felemelkedés társadalmi-kulturális feltételei című kutatás zárójelentése. Budapest: Tárki.

Tóth D. (2015): A korrupciós bűncselekmények szabályozásának története Magyarországon. Büntetőjogi Szemle, 3, 107-112.

Vasvári T. - Vargha B. - Martus B. - Németh E. (2017): Etikus vezetés és szervezeti struktúra - A hazai közintézmények integritási helyzetének összefüggése az etikus vezetés elterjedtségével és a szervezeti sajátosságokkal. Köz-Gazdaság, 29-55. 
1. melléklet: Az alapsokaságban és a mintában lévő intézmények intézménycsoportok szerint

\begin{tabular}{l|c|c}
\multicolumn{1}{r}{$\quad$ Intézménycsoport } & Alapsokaság & Válaszolt \\
\hline Általános és középfokú oktatás & 160 & 68 \\
\hline Egészségügyi intézmények & 202 & 110 \\
\hline Egyéb - igazgatási tevékenység & 2694 & 185 \\
\hline Egyéb tevékenységek & 391 & 27 \\
\hline Felsőfokú oktatás & 29 & 22 \\
\hline Független államhatalmi szervezetek & 37 & 10 \\
\hline Helyi önkormányzat & 4863 & 1575 \\
\hline Igazságszolgáltatás & 28 & 27 \\
\hline Kormányzati szervezetek & 9 & 9 \\
\hline Kulturális intézmények & 765 & 248 \\
\hline Óvoda, bölcsőde & 2540 & 570 \\
\hline Rend- és honvédelem & 142 & 118 \\
\hline Szociális ellátóintézmények & 951 & 338 \\
\hline Területi igazgatási szervezetek & 20 & 20 \\
\hline Tudományos kutatás, fejlesztés & 39 & 19 \\
\hline Összesen & 12870 & 3346
\end{tabular}

2. sz. melléklet: A robusztusság vizsgálata az egyes intézménycsoportok kihagyásával

\begin{tabular}{l|c} 
Ha az összes olyan intézménycsoportot tekintjük, ahol a válaszadók legalább & 0,58 \\
\hline $10 \%-a$ rendelkezik hatósági jogkörrel & \\
\hline Ha kihagyjuk a... intézménycsoportot, akkor a kapcsolat erőssége és iránya: & 0,51 \\
\hline Felsőfokú oktatás & 0,53 \\
\hline Óvoda, bölcsőde & 0,55 \\
\hline Rend- és honvédelem & 0,55 \\
\hline Területi igazgatási szervezetek & 0,56 \\
\hline Egyéb tevékenységek & 0,58 \\
\hline Egészségügyi intézmények & 0,59 \\
\hline Egyéb-igazgatási tevékenység & 0,61 \\
\hline Szociális ellátóintézmények & 0,67 \\
\hline Helyi önkormányzat & 0,68 \\
\hline Független államhatalmi szervezetek & 0,69 \\
\hline Igazságszolgáltatás & 0,69
\end{tabular}

